\title{
LA-UR-12-23255
}

Approved for public release; distribution is unlimited.

Title:

CMR Shuffler System: Passive Mode Calibration and Certification Report

Author(s):

Frame, Katherine C.

Gomez, Cipriano D.

Salazar, William R.

Mayo, Douglas R.

Vigil, Georgiana M.

Crooks, William J.

Stange, Sy

Intended for:

Report

\section{- Losalamos}

\author{
EST. 1943
}

Disclaimer:

Los Alamos National Laboratory, an affirmative action/equal opportunity employer,is operated by the Los Alamos National

Security, LLC for the National NuclearSecurity Administration of the U.S. Department of Energy under contract DE-AC52-06NA25396.

By approving this article, the publisher recognizes that the U.S. Government retains nonexclusive, royalty-free license to

publish or reproduce the published form of this contribution, or to allow others to do so, for U.S. Government purposes.

Los Alamos National Laboratory requests that the publisher identify this article as work performed under the auspices of the

U.S. Departmentof Energy. Los Alamos National Laboratory strongly supports academic freedom and a researcher's right to publish; as an institution, however, the Laboratory does not endorse the viewpoint of a publication or guarantee its technical correctness. 


\title{
CMR Shuffler System: Passive Mode Calibration and Certification Report
}

\author{
Katherine C. Frame \\ William J. Crooks \\ Cipriano D. Gomez \\ Douglas R. Mayo \\ William R. Salazar \\ Sy Stange
}

Georgiana M. Vigil

Los Alamos National Laboratory

LA-UR-12-XXXXX 
CMR Shuffler System in Passive Mode

Executive Summary:

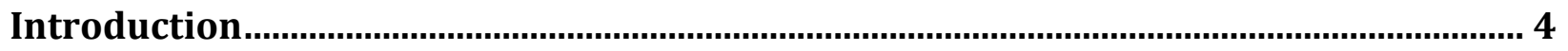

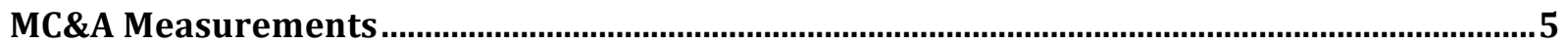

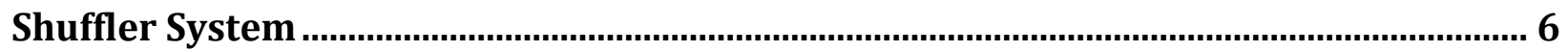

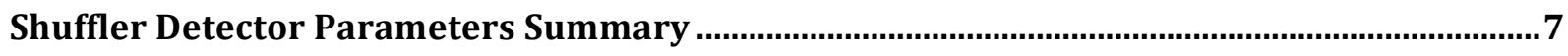

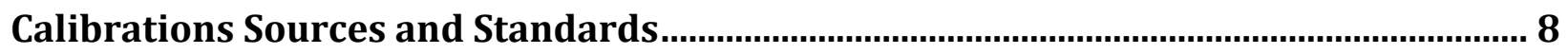

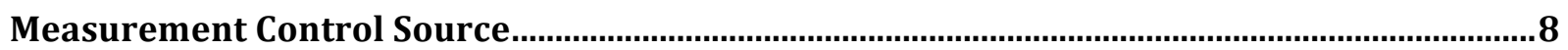

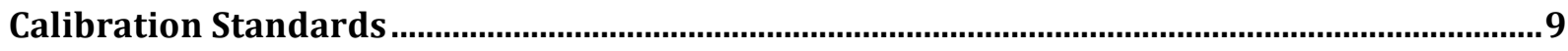

Passive Mode CMR Shuffler system Calibration ...............................................................10

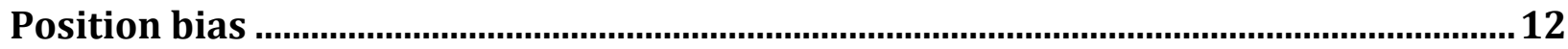

Summary and Conclusions........................................................................................... 12

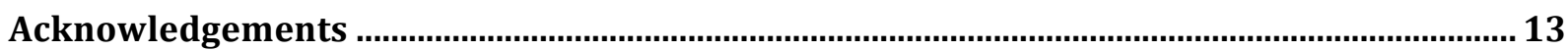

References .............................................................................................................................. 13

AppendiX A 
CMR Shuffler System in Passive Mode

\section{EXECUTIVE SUMMARY:}

Los Alamos National Laboratory has a number of spherical confinement vessels (CVs) remaining from tests involving nuclear materials. These vessels have an inner diameter of 6 feet with 1 to 2 inch thick steel walls. The goal of the Confinement Vessel Disposition (CVD) project is to remove debris and reduce contamination inside the vessels. As debris is removed from the vessels, material will be placed in waste drums. Far-field gamma ray assay will be used to determine when a drum is nearing a ${ }^{239} \mathrm{Pu}$ equivalent mass of less than $200 \mathrm{~g}$. The drum will then be assayed using a waste drum shuffler operated in passive mode using a neutron coincidence counting method for accountability.

This report focuses on the testing and calibration of the CMR waste drum shuffler in passive mode operation. Initial testing was performed to confirm previously accepted measurement parameters. The system was then calibrated using a set of weapons grade $\mathrm{Pu}\left(\mathrm{WGPu},{ }^{239} \mathrm{Pu}>\right.$ 93\%) oxide standards placed inside a 55 gallon drum. The calibration data ranges from $\mathrm{Pu}$ mass of $0.5 \mathrm{~g}$ to $188.9 \mathrm{~g}$.

The CMR waste drum shuffler has been tested and calibrated in passive mode in preparation for safeguards accountability measurements of waste drums containing material removed from CVs for the CVD project. 


\section{INTRODUCTION}

The Confinement Vessel Disposition (CVD) project is part of a larger effort to consolidate and dispose of non-programmatic special nuclear materials (SNM) at Los Alamos National Laboratory (LANL). The charter of the CVD project is to remove debris and contamination from vessels that were used in 1970s-era explosives experiments. These spherical vessels have a 6-ft $(1.83-\mathrm{m})$ inner diameter and 1- or 2-in $(25.4-$ or $50.8-\mathrm{mm})$ thick steel walls, weighing upwards of $7500 \mathrm{lbs}(3300-\mathrm{kg})$. Figure 1 provides a photographic example of several of these vessels in storage at LANL. Each vessel contains $\sim 500 \mathrm{lb}$ of radioactive debris and may include up to $11 \mathrm{lb}$ $(5-\mathrm{kg}){ }^{239} \mathrm{Pu}$ equivalent in the form of actinide metals and oxides mixed in a matrix of metal (steel, brass, aluminum), beryllium, lead, powdered silica, graphite, electrical wires and other hardware. Figure 2 gives an example of the debris inside of a vessel prior to and after cleanout from a previous campaign in which hand tools were used to remove debris and reduce contamination in the vessel.

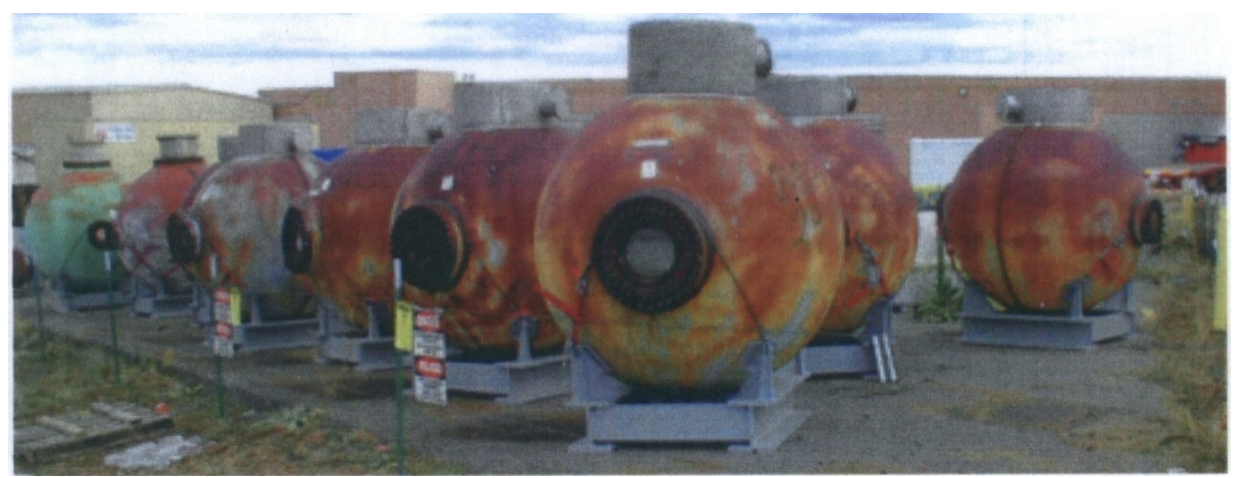

Figure 1. Several confinement vessels pictured in their current storage location at LANL.
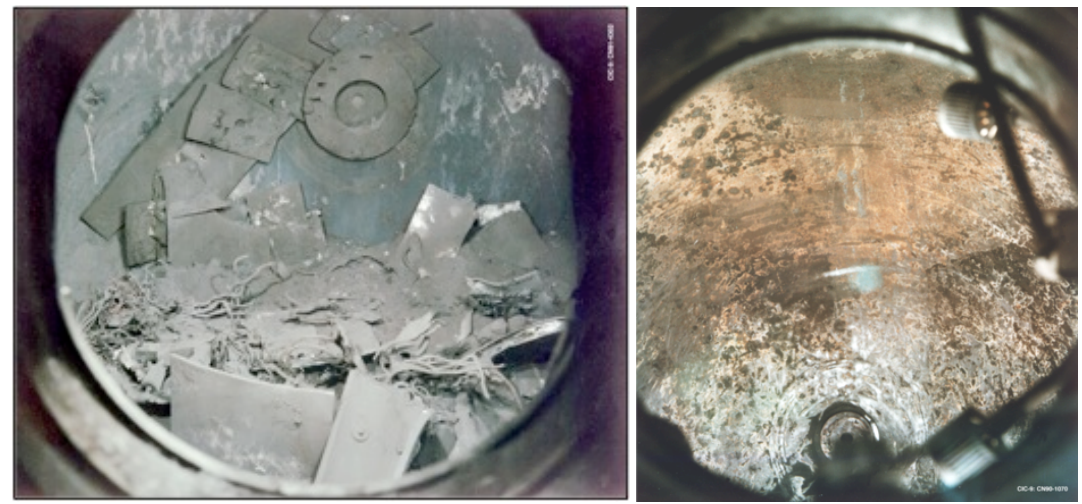

Figure 2. Inside view showing confinement vessel before (left) and after (right) cleanout.

The current CVD project has included equipment and procedural upgrades for the removal of debris to include a robotic arm and glove box workstation in order to improve contamination control and reduce worker risk during cleanout. Figure 3 shows an artist's conception of the confinement vessel during the cleanout process. While the vessel is supported on a stand, the glove box workstation will be connected through one port on the vessel and the robotic arm will be inserted through another port. The robotic arm can be fitted with different attachments for cutting up large metal pieces, clearing debris, and scrubbing the walls of the vessel. Lights and cameras may also be attached for inspection during and after the cleanout. Within the glove box, 
hand tools may be used to further reduce the size of metal pieces. Material that can be used in programmatic applications will be recovered and non-programmatic materials will be bagged out and placed in waste drums for disposition.

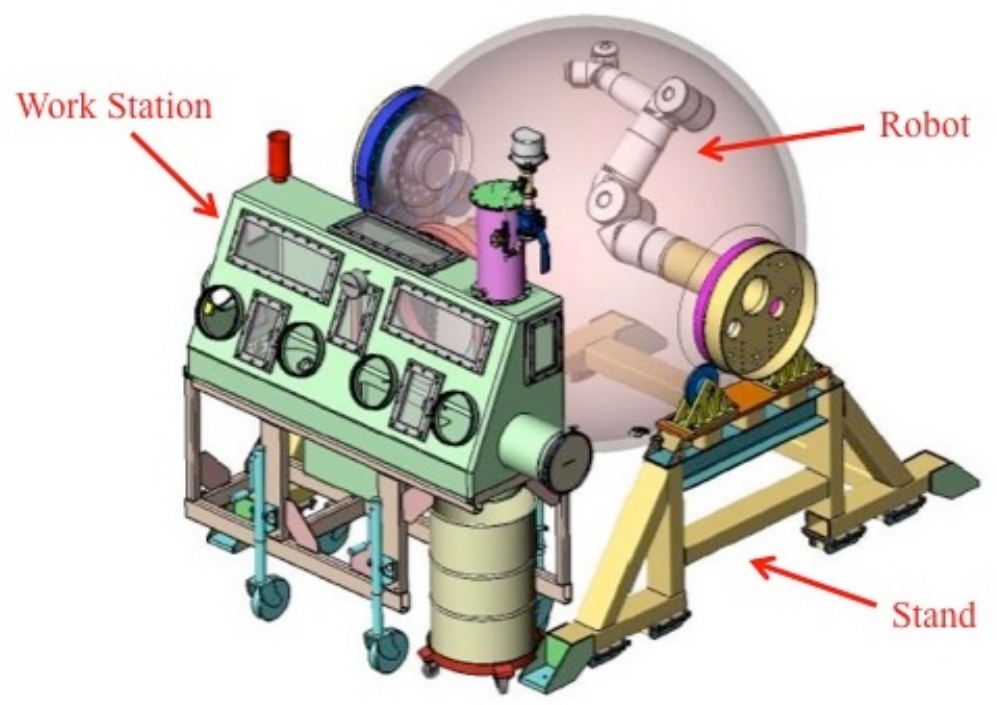

Figure 3. Configuration of the confinement vessel, glove box workstation, and robotic arm during the performance of cleanout operations.

\section{MC\&A Measurements}

We were tasked to design, develop, implement, and certify nondestructive assay systems [1] that would meet all of the various stages associated with the disposition of materials from the confinement vessels (CVs). In order to meet the safeguards requirements, a set of measurement methods have been accepted for use on this project. A combination of neutron and gamma ray measurements will be used for Materials Control and Accountability (MC\&A) throughout the CVD project. Measurements will be performed in the following sequence for the disposition of each confinement vessel.

1. Gamma ray assay of the glove box workstation to determine holdup of SNM from previous confinement vessel cleanout (presumed to be zero prior to cleanout of the first $\mathrm{CV}$, then some small value as the campaign progresses).

2. Neutron assay [2][3] of the confinement vessel before processing to verify and fully document the initial material inventory.

3. Far-field gamma-ray assay of port covers after removal to determine their levels of contamination.

4. Long-dwell-time gamma-ray assay of the first waste drum to establish isotopic composition of the SNM in the vessel. 
5. Far-field gamma ray assay of each waste drum to assess when the drum is reaching an amount below the maximum quantity of ${ }^{239} \mathrm{Pu}$ equivalent $(<200 \mathrm{~g})$ as well as to determine the ratio of uranium to plutonium content.

6. Neutron assay of waste drums using a waste drum shuffler operated in passive mode to quantify SNM content in each drum [4][5].

7. Neutron measurement of the confinement vessel upon completion of cleanup operations to determine the residual content of SNM [3].

8. Gamma ray measurement of the glove box workstation upon completion of debris removal from the vessel to determine an ending holdup value for the workstation.

This paper focuses on the passive shuffler assay system that will be used to perform neutron coincidence counting measurements of the waste drums containing less than $200 \mathrm{~g}{ }^{239} \mathrm{Pu}$ equivalent.

\section{SHUFFLER SYSTEM}

The shuffler is located in the nondestructive assay (NDA) laboratory (Room S103) of the Chemistry and Metallurgy Research (CMR) facility and is operated by the CMR Operations (CMR-OPS) group, NDA laboratory personnel and Nuclear Nonproliferation Division (NDivision) technical staff. Canberra Industries fabricated the shuffler, which was designed by the Safeguards Science and Technology Group (NEN-1) in the NEN-Division [6][7]. The shuffler can be used to measure items of any size and geometry up to 55-gallon drums. The shuffler is a passive/active neutron (PAN) instrument that assays plutonium (Pu) and/or uranium. The CMR Shuffler will only be used in the passive mode for neutron assay of waste drums for the CVD project.

In the passive mode, the PAN shuffler acts as a neutron coincidence counter (NCC) for measuring spontaneously fissioning isotopes, ${ }^{238} \mathrm{Pu},{ }^{240} \mathrm{Pu}$, and ${ }^{242} \mathrm{Pu}$. $\mathrm{Pu}$ is assayed in this mode by counting multiples of coincident neutrons from the spontaneously fissioning even $\mathrm{Pu}$ isotopes using the International Neutron Coincidence Counting (INCC) software. In the active mode (which will not be enabled), the shuffler interrogates (induces fissions in) the fissile material (for example, uranium) by neutrons to induce fissions and counts the resulting delayed neutrons from the precursors (fission fragments). The interrogating neutrons come from a ${ }^{252} \mathrm{Cf}$ (californium) source which is "shuffled" a number of times from a shielded position to the assay chamber and back by a computer-controlled stepping motor. Banks of polyethylene-moderated helium $\left({ }^{3} \mathrm{He}\right)$ detectors surround the assay chamber and are used to count neutrons in either mode of operation.

The Shuffler hardware includes a shuffler body and an electronics rack. A photograph of the CMR Shuffler body is shown in Figure 2. The detector consists of eight banks of ${ }^{3} \mathrm{He}$ tubes embedded in high-density polyethylene moderator. Six detector banks surround an assay chamber with a rotating floor. More detail can be found in [6] and [7]. 
CMR Shuffler System in Passive Mode

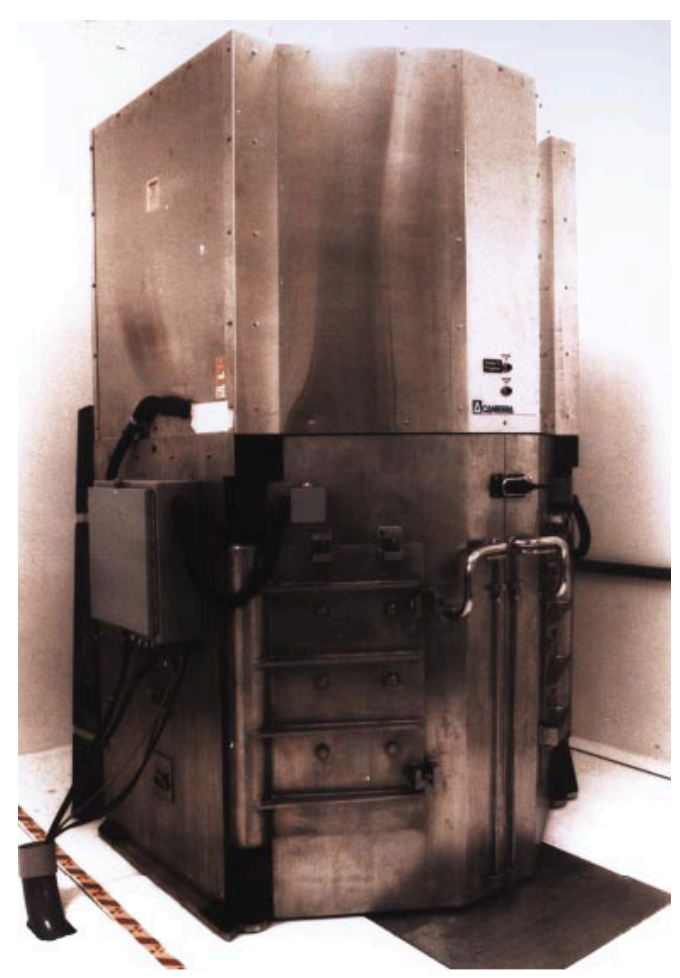

Figure 4. Photograph of the CMR waste drum shuffler body.

\section{Shuffler Detector Parameters Summary}

The passive shuffler detector parameters are shown in Table 1. The die-away, predelay, gate width and dead-time parameters were taken from the parameter settings previously stored in the system. Measurements were performed to confirm the die-away and gate width settings, and the efficiency was also measured. During initial testing, unusual fluctuations in background count rates were observed in the bottom bank of detectors. The decision was made to disable this bank to reduce measurement uncertainty due to these fluctuations. This bank is also disabled in the TA-55 shuffler.

Table 1. Shuffler detector parameters.

\begin{tabular}{|l|c|r|}
\hline Die-away & $\tau[\mu \mathrm{s}]$ & 71 \\
\hline Predelay & $\mathrm{P}[\mu \mathrm{s}]$ & 4.5 \\
\hline Gate Width & $\mathrm{GW}[\mu \mathrm{s}]$ & 90 \\
\hline Efficiency & $\varepsilon$ & $14.7 \%$ \\
\hline Dead-time & $\mathrm{A}[\mu \mathrm{s}]$ & 0.4383 \\
\hline & $\mathrm{B}\left[\mu \mathrm{s}^{2}\right]$ & 0.1461 \\
\hline High Voltage & $\mathrm{HV}(\mathrm{V})$ & 1680 \\
\hline
\end{tabular}


CMR Shuffler System in Passive Mode

The die-away time was measured using a 252Cf source and the following method [9]. The probability $(d p)$ for capturing a neutron in a ${ }^{3} \mathrm{He}$ tube in a time $d t$ is given approximately by

$$
d p=\frac{1}{\tau} \exp (-t / \tau) \cdot d t
$$

where $t$ is the time from emission to capture and $\tau$ is the detector die-away time. The probability $(p)$ of detecting a neutron in the coincidence gate is thus

$$
p=\exp (-P / \tau) \cdot[1-\exp (-G / \tau)],
$$

where $P$ is the predelay and $G$ is the gate length. Using the above equation, the ratio of the doubles coincidents counts at at two different gate widths, $128 \mu \mathrm{s}$ and $64 \mu \mathrm{s}$, is given by

Solving this equation for $\tau$ gives

$$
\frac{R_{128}}{R_{64}}=\frac{1-\exp (-128 / \tau)}{1-\exp (-64 / \tau)} .
$$

$$
\tau=\frac{-64}{\ln \left(\frac{R_{128}}{R_{64}}-1\right)}
$$

The die-away time measured using this method was found to be $68.3 \mu \mathrm{s}$. An optimal gate-width has been shown to be $1.27 * \tau=87 \mu$ s [1]. These values are comparable to the parameter settings of $71 \mu \mathrm{s}$ die-away and $90 \mu$ s gate width.

The efficiency was measured to be $14.7 \%$ by placing a ${ }^{252} \mathrm{Cf}$ source on a stand in the center of the assay chamber. The efficiency was calculated as the ratio of the measured singles rate to the known yield of the source. NIST Source traceability measurements were performed for the ${ }^{252} \mathrm{Cf}$ source (ID A7-258) using the SNAP-III detector on December $22^{\text {nd }}$ and $23^{\text {rd }}$ of 2009 . The source characteristics were originally reported to be $500 \mu \mathrm{Ci}$ on August $15^{\text {th }}$ of 2002 . Measurements on December $21^{\text {st }}$ of 2009 revealed a neutron yield of $2.81 \times 10^{5} \mathrm{n} / \mathrm{s}$. The value previously stored was $15.4 \%$. With the bottom bank enabled, we measured an efficiency of $15.2 \%$.

\section{CALIBRATIONS SOURCES AND STANDARDS}

\section{Measurement Control Source}

The ${ }^{252} \mathrm{Cf}$ source, A7-258, that was used to measure the efficiency was also used for measurement control during calibration of the system. 
CMR Shuffler System in Passive Mode

\section{Calibration Standards}

A set of weapons grade $\mathrm{Pu}\left(\mathrm{WGPu},{ }^{239} \mathrm{Pu}>93 \%\right)$ standards were used to calibrate the system. The PDP and RANT series contain high purity plutonium oxide $\left(\mathrm{PuO}_{2}\right)$ dispersed in diatomaceous earth. Certificates of content and traceability are included in Appendix A with the exception of the PDP30.0Pu2.0mm standard. This standard contains large particle $(2.0 \mathrm{~mm})$ oxide mixed with the diatomaceous earth and we have included a Los Alamos interoffice memorandum, which gives the Pu mass and isotopic composition of this standard. Table 2 contains source identifications along with the declared $\mathrm{Pu}$ mass and effective ${ }^{240} \mathrm{Pu}\left({ }^{240} \mathrm{Pu}_{\mathrm{eff}}\right)$ mass on the date that calibration data were collected. The calibration data ranges from $\mathrm{Pu}$ masses of $0.5 \mathrm{~g}$ to $188.9 \mathrm{~g} \mathrm{(}{ }^{240} \mathrm{Pu}_{\text {eff }}$ masses of $0.03 \mathrm{~g}$ to $\left.13 \mathrm{~g}\right)$.

Table 2 Calibration Standards.

\begin{tabular}{|l|l|l|l|}
\hline Source ID & $\begin{array}{l}\text { Measurement } \\
\text { Date }\end{array}$ & $\begin{array}{l}{ }^{240} \mathrm{Pu}_{\text {eff }} \\
\text { mass }(\mathrm{g})\end{array}$ & $\begin{array}{l}\text { Pu } \\
\text { Mass (g) }\end{array}$ \\
\hline PDP0.50Pu & $10 / 18 / 11$ & 0.03 & 0.48 \\
\hline PDP1.0Pu & $10 / 19 / 11$ & 0.07 & 0.95 \\
\hline PDP3.0Pu & $10 / 19 / 11$ & 0.18 & 3.04 \\
\hline PDP5.0Pu & $10 / 17 / 11$ & 0.34 & 4.99 \\
\hline PDP10.0Pu & $10 / 14 / 11$ & 0.61 & 10.04 \\
\hline PDP5.0Pu and PDP10.0Pu & $10 / 18 / 11$ & 0.95 & 15.04 \\
\hline PDP20.0Pu & $10 / 17 / 11$ & 1.37 & 20.00 \\
\hline PDP30.0Pu2.0mm & $10 / 17 / 11$ & 2.08 & 30.26 \\
\hline PDP30.0Pu2.0mm and PDP10.0Pu & $10 / 18 / 11$ & 2.69 & 40.31 \\
\hline RANT50-1 & $11 / 28 / 11$ & 3.43 & 49.96 \\
\hline PDP30.0Pu2.0mm and PDP20.0Pu & $10 / 18 / 11$ & 3.45 & 50.26 \\
\hline PDP30.0Pu2.0mm, PDP20.0Pu and PDP10.0Pu & $10 / 18 / 11$ & 4.06 & 60.31 \\
\hline RANT50-1 and RANT50-2 & $11 / 28 / 11$ & 6.86 & 99.89 \\
\hline RANT50-1, RANT50-2 and RANT50-3 & $11 / 28 / 11$ & 10.29 & 149.85 \\
\hline $\begin{array}{l}\text { RANT50-1, RANT50-2, RANT50-3, PDP20.0Pu and } \\
\text { PDP5.0Pu }\end{array}$ & $11 / 28 / 11$ & 12.00 & 174.81 \\
\hline $\begin{array}{l}\text { RANT50-1, RANT50-2 RANT50-3, PDP1.0Pu, } \\
\text { PDP3.0Pu, PDP5.0Pu, PDP10.0Pu and PDP20.0Pu }\end{array}$ & $11 / 29 / 11$ & 12.86 & 188.88 \\
\hline
\end{tabular}




\section{PASSIVE MODE CMR SHUFFLER SYSTEM CALIBRATION}

Verification measurements will be performed on 55-gallon waste drums containing material removed from CVs. High resolution gamma ray assay will be used to measure the relative isotopic content of the material and far-field gamma-ray assay will be used to determine when a drum is nearing a ${ }^{239} \mathrm{Pu}$ equivalent mass of less than $200 \mathrm{~g}$.

The calibration is based on doubles coincidence counting. Waste drums from vessels containing beryllium will require expert review. Beryllium has a very high cross-section for $(\alpha, n)$ interactions, and these neutrons may induce fissions that will increase the doubles rate. Additional review will be needed to estimate a correction to the doubles rate that can then be used to determine the mass.

Prior to performing calibration measurements, background measurements were performed with an empty assay chamber. The standards were then placed inside of a 55-gallon drum with positioning tubes that were fabricated to hold these types of standards at various positions within the drum. There are 3 tubes, aligned vertically within the drum. Tube 1 is at the center, Tube 2 is approximately half way between the center and the outer edge of the drum and Tube 3 is near the outer edge of the drum. Each tube has 3 vertical positions within it. For cases where a single standard was measured, the standards were positioned in the vertical center of Tube 2 . For cases where 2 and 3 standards were measured together, the standards were positioned in the vertical centers of Tube 1 and Tube 2 (for 2 standards) or Tube 1, Tube 2, and Tube 3 (for 3 standards). In cases where 5 standards were measured, the center and upper positions were used, and in the case where 8 standards were measured all positions except for the bottom of Tube 3 was used.

Figure 5 shows the doubles coincident count rate as a function of ${ }^{240} \mathrm{Pu}_{\text {eff }}$ mass from $0.03 \mathrm{~g}$ to 13 $\mathrm{g}$ (Pu masses of $0.03 \mathrm{~g}$ to $13 \mathrm{~g}$ ). Error bars are within the polymarker. A linear fit was performed on these data and the result is also shown in Figure 5 as a straight line. The calibration curve has the functional form, Doubles Rate $=16.12659 \times{ }^{240} \mathrm{Pu}_{\text {eff }}$ mass. 
CMR Shuffler System in Passive Mode

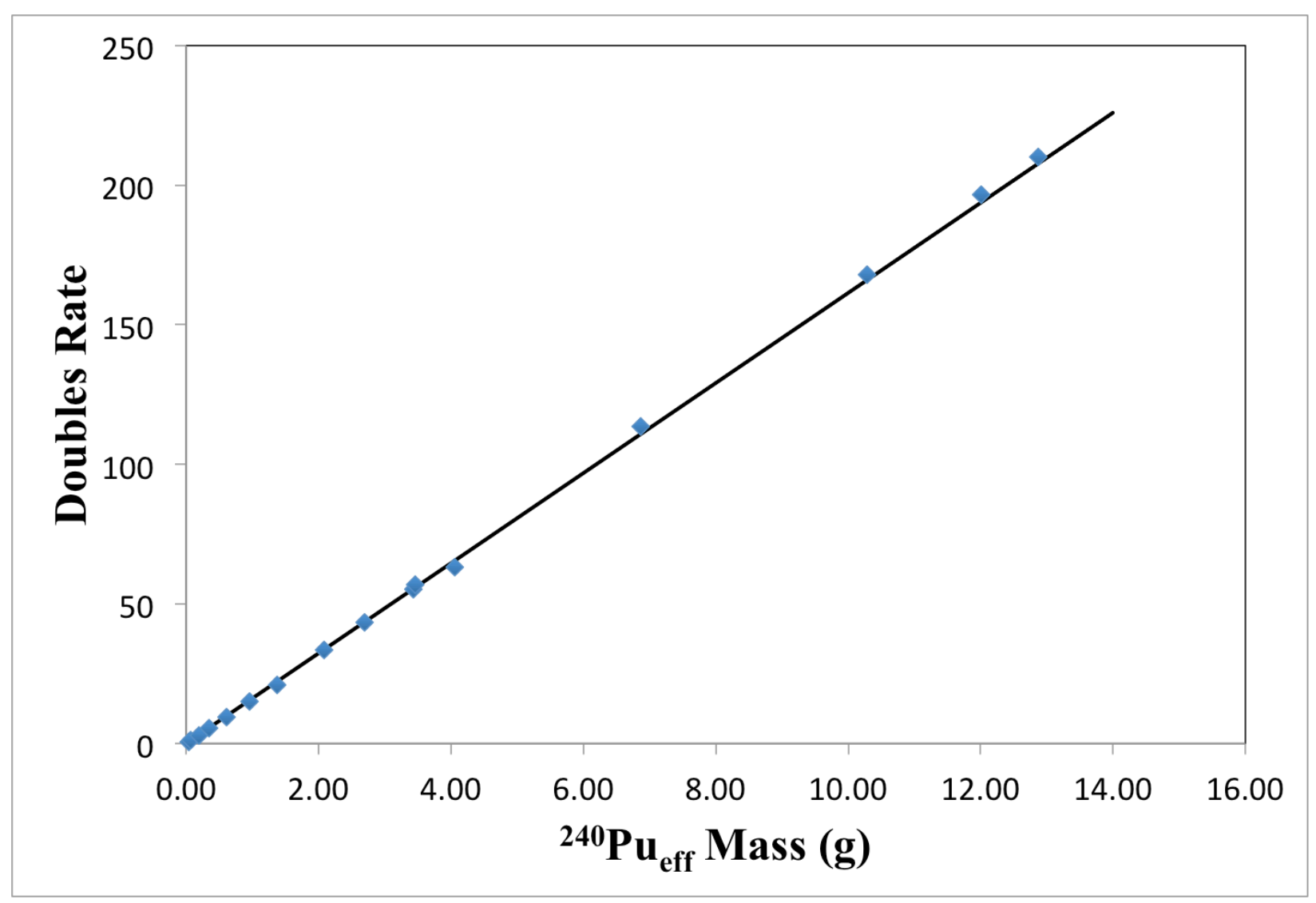

Figure 5 Calibration curve, Doubles rate as a function of ${ }^{240} \mathrm{Pu}_{\text {eff }}$ mass.

To verify the calibration, a combination of standards was measured that was not used for calibration. The RANT50-1, RANT50-2, and PDP20.0Pu standards were placed in the vertical centers of Tubes 1, 2, and 3 of the drum. A verification measurement was performed and the results are shown in Table 3. The difference between the declared and assay masses agree well within the uncertainty.

Table 3. Verification results for a combined $\mathrm{Pu}$ mass of $120 \mathrm{~g}$.

$$
\begin{aligned}
\text { Assay }{ }^{240} \mathrm{Pu}_{\text {eff }} \text { Mass }(\mathrm{g}): & 8.200 \pm 0.068 \\
{ }^{240} \mathrm{Pu}_{\text {eff }}(\%): & 6.866 \\
\text { Assay Pu Mass (g): } & 119.437 \pm 0.996
\end{aligned}
$$

Declared ${ }^{240} \mathrm{Pu}_{\text {eff }}$ Mass (g): $\quad 8.232$

Declared Pu Mass (g): 119.895

Declared - Assay Pu Mass (g): $0.458 \pm 0.996$

Declared - Assay Pu Mass (\%): $0.382 \pm 0.830$ 


\section{POSITION BIAS}

When a waste drum is assayed, the exact distribution of material within the drum will be unknown. As described above, the calibration was performed with the material distributed near the vertical center of the drum. In the worst-case scenario, all of the material may be located at one particular location and the assay result may be biased. To estimate an uncertainty, measurements were performed with one of the $50 \mathrm{~g}$ standards (RANT50-1) placed in multiple locations in the drum and the doubles rate was compared to the doubles rate when the source was placed in the vertical center of Tube 2 . The largest deviation was found with the source positioned in the bottom of Tube 1. With the bottom detector bank disabled, this location has the poorest solid angle coverage. Unfortunately, it is also likely that material will settle at the bottom of the drum.

The doubles rate for the source at the nominal location is 1.36 times that of the doubles rate for the source located a the bottom of the drum. If we were to assay a waste drum assuming a distribution similar to that of the calibration measurements, but the material is actually concentrated at the bottom of the drum, we would underestimate the amount of material and there could be as much as $36 \%$ more material than the assay amount. If we were to assay a drum where the material is near the top of the drum, we would overestimate the amount by only $3.5 \%$.

To accommodate a position bias, we will apply an asymmetric uncertainty of $36 \%$ in the positive direction and $3.5 \%$ in the negative direction. This will be added in quadrature to the assay uncertainty reported by INCC. This uncertainty will be the dominant uncertainty.

\section{SUMMARY AND CONCLUSIONS}

The CMR waste drum shuffler will be operated in passive mode to perform assay measurements of waste drums containing material that has been removed from CVs. The drums will be measured using far field gamma-ray assay to ensure they are below the $200 \mathrm{~g}{ }^{239} \mathrm{Pu}$ equivalent mass limit prior to shuffler assay.

The system has been calibrated for ${ }^{240} \mathrm{Pu}_{\mathrm{eff}}$ masses from $0.03 \mathrm{~g}$ to $13 \mathrm{~g}$ (corresponding to $0.5 \mathrm{~g}$ to $189 \mathrm{~g} \mathrm{WGPu}$ ). The standards used for calibration contain high purity $\mathrm{PuO}_{2}$ mixed with diatomaceous earth. The calibration measurements were performed with standards located near the vertical center of a 55 gallon drum configured for positioning these standards in a variety of locations. The calibration was verified by performing assay measurements on a combination of standards not used for calibration. Assayed masses agreed with declared masses within $1 \sigma$, statistical error.

The systematic uncertainty due to position bias was estimated by placing a standard at multiple locations within the drum used for calibration. It was found to have the largest deviation at the bottom of the drum where is also most likely that material will settle prior to assay. To accommodate a position bias, an asymmetric uncertainty of $+36 \%$ and $-3.5 \%$ will be added in quadrature to the assay uncertainty reported by INCC.

One limitation to the validity of the calibration curve is the assay of material containing beryllium, and this will require expert review. 
The CMR waste drum shuffler has been tested and calibrated in preparation for and safeguards measurements of waste drums containing material removed from CVs during cleanout.

\section{Acknowledgements}

We gratefully acknowledge many helpful hours spent in collaboration with our colleagues who support the Chemistry and Metallurgy Research Facility (CMR) operations. In addition, we acknowledge financial support from DOE.

\section{REFERENCES}

[1] D. Reilly et al., Passive Nondestructive Assay of Nuclear Materials, NUREG/CR-5550, LAUR-90-732, United States Nuclear Regulatory Commission, March 1991.

[2] M. Krick, "240Pu-effective Mass Formula for Coincidence Counting of Plutonium with Shift Register Electronics," in "Nuclear Safeguards Program Status Report, May-August 1977,’ J. L. Sapir, Comp., Los Alamos Scientific Laboratory report LA-7030-PR (1977), p. 16.

[3] K. Frame et al., "Confinement Vessel Assay System Design and Implementation Report", Los Alamos National Laboratory internal document, 2012.

[4] P. Rinard, “Application Guide to Shufflers," Los Alamos National Laboratory document LA-13819-MS, September 2001.

[5] P. Rinard, "Shuffler Instruments for the Nondestructive Assay of Fissile Materials," Los Alamos National Laboratory document LA-12105, May 1991.

[6] P. Rinard et al., Hardware Manual for Waste Drum Shufflers Model JCC-92, Canberra Industries, Meriden, CT, November 1993.

[7] P. Rinard et al., "Los Alamos Waste Drum Shufflers Users Manual," Los Alamos National Laboratory document LA-UR-93-3148, August 1993.

[8] W. Harker and M. Krick, "Neutron Coincidence Counting Software for Windows," Los Alamos National Laboratory document, LA-UR-96-360, 1996.

[9] P. Santi et al., "Nondestructive Assay Inspector Training Course", Los Alamos Laboratory Document LA-UR-06-5614, 2006.

[10] N. Ensslin et al., "Application Guide to Neutron Multiplicity Counting," Los Alamos National Laboratory document LA-13422-M, 1998. 


\title{
Los Alamos National Laboratory Certifítate of Content ant Trateability
}

\author{
$\mathrm{PuO}_{2}$-Diatomaceous Earth Standard PDPO.1\%Pu
}

This NDA standard contaims high purity plutonizm dioxide dispersed in diatomaceous earth. Quantitative information and uncertainties on the nuclear content of this WRM are listed below. Complete information regarding the $\mathrm{Pu}$ and $\mathrm{Am}$ content, $\mathrm{Pu}$ isotopic ratios, chemical composition, elemental impurities, containment, and fabrication procedures are retained in files by the Los Alamos National Laboratory Inorganic Elemental Analysis Group.

\section{NUCLEAR MATERIAL CONTENT}

The nuclear material content and total alpha activity for this standard are listed below. Also listed are overall uncertainty estimates at $95 \%$ confidence intervais (C) for each component.

\begin{tabular}{|c|c|c|}
\hline Component & Quantity or Vafie & $95 \% \mathrm{CI}$ \\
\hline $\mathrm{PuO}_{2}$ in standard & 0.11587 grams & $\pm 0.00023 \mathrm{grams}^{(\mathrm{a})}$ \\
\hline Pu Assay & $87.915 \%$ of $\mathrm{PuO}_{2}$ & $\pm 0.065 \%$ \\
\hline Pu in standard & $0.10187 \mathrm{gram}$ & $\pm 0.00021 \mathrm{grams}^{(\mathrm{c})}$ \\
\hline${ }^{2 \pi i}$ Am Assay & $979.2 \mathrm{\mu g} / \mathrm{g} \mathrm{PuO}_{2}{ }^{\star}$ & $\pm 0.2 \mu \mathrm{g} / \mathrm{g}$ (d) \\
\hline${ }^{24 \mathrm{Am}}$ in standard & $0.1135 \mathrm{mg}$ & $\pm 0.0003 \mathrm{mg}^{(e)}$ \\
\hline \multicolumn{3}{|l|}{ Isotopic Weight Fraction } \\
\hline${ }^{238} \mathrm{Pu}$ & 0.000151 & $\pm 0.000005^{(n)}$ \\
\hline${ }^{39} \mathrm{p} \mathrm{u}$ & 0.929661 & $\pm 0.000015^{(5)}$ \\
\hline${ }^{240} \mathrm{Pu}$ & 0.067202 & $\pm 0.000007^{(n)}$ \\
\hline${ }^{241} \mathrm{Pu}$ & $0.002327^{*}$ & $\pm 0.000010^{(n)}$ \\
\hline${ }^{242} \mathbf{P u}$ & 0.000659 & $\pm 0.000003^{(n)}$ \\
\hline Total Alpha Activity in standard & $\begin{array}{c}8.079 \mathrm{mCi}^{\mathrm{*}} \\
2.989 \mathrm{E}+08 \mathrm{~Bq}\end{array}$ & $\begin{array}{l} \pm 0,023 \mathrm{mCi}(s) \\
\pm 9 \mathrm{E}+05 \mathrm{~Bq}(w)\end{array}$ \\
\hline
\end{tabular}

"Measured valu $10 / 2 / 96$
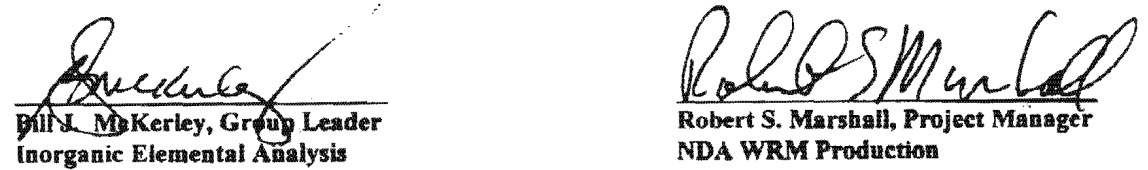


\title{
Los Alamos National Laboratory Certifitate of Content ami $\mathbb{T r a t e a b i l i t y}$
}

\author{
$\mathrm{PuO}_{2}$-Diatomaceous Earth Standard PDP0.50Pu
}

This NDA standard contains high purity plutonium dioxide dispersed in diatomaceous earth. Quantitative information and uncertainties on the nuclear content of this WRM are listed below. Complete information regarding the $\mathrm{Pu}$ and Am content, $\mathrm{Pu}$ isotopic ratios, chemical composition, elemental impurities, containment, and fabrication procedures are retained in filles by the Los Alamos National Laboratory Inorganic Elemental Analysis Group.

NUCLEAR MATERLAL CONTENT

The muclear material content and total alpha activity for this standard are listed below. Also listed are overall uncertainty estimates at $95 \%$ confidence intervals (CD) for each component.

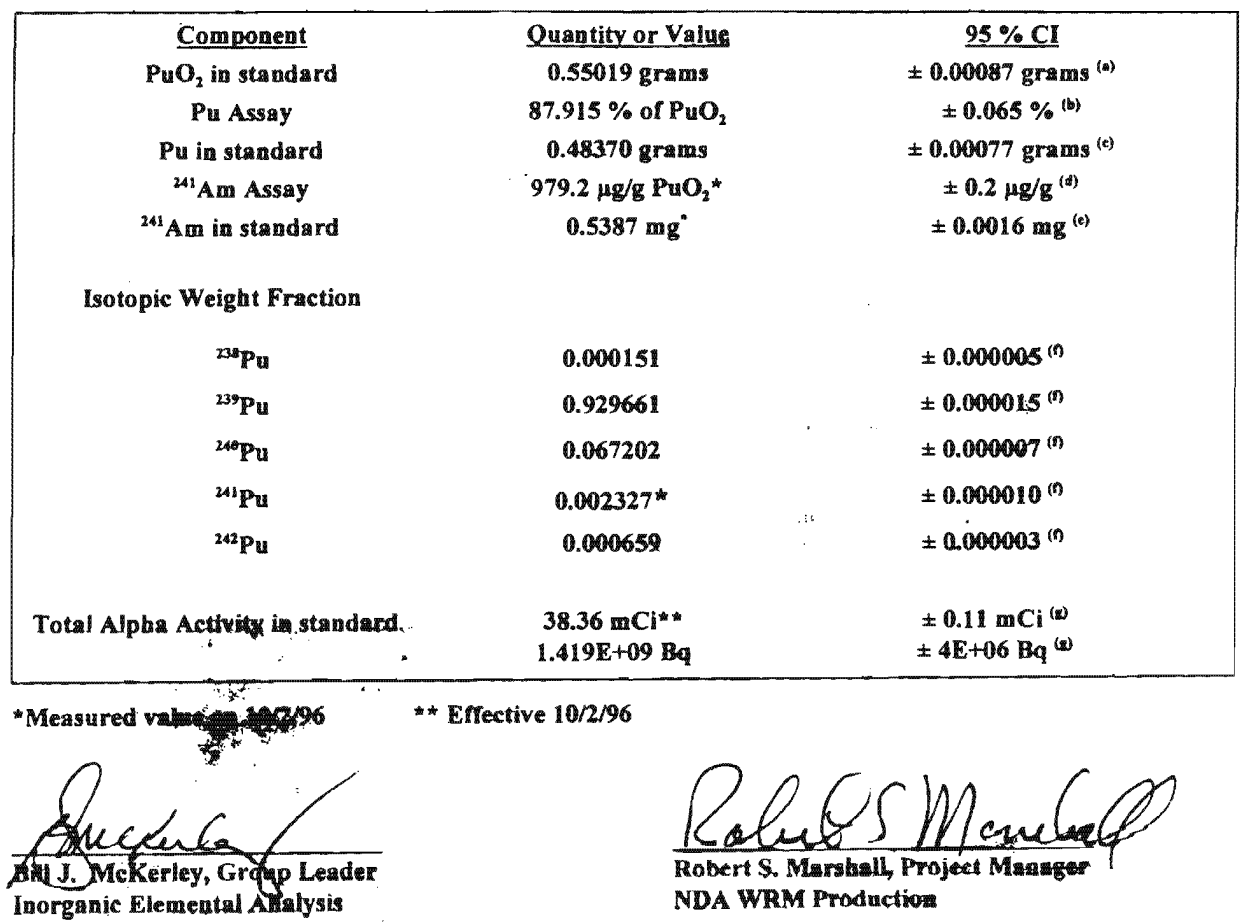




\title{
Los Alamos National Laboratory Certifitate of Content and $\mathbb{C r a t e a b i l i t y ~}$
}

\author{
$\mathrm{PuO}_{2}$-Diatomaceous Earth Standard PDP1.0Pu
}

This NDA standard contains high purity plutonium dioxide dispersed in diatomaceous earth. Quantitative information and uncertainties on the nuclear content of this WRM are listed below. Complete information regarding the Pu and Am content, Pu isotopic ratios, chemical composition, elemental impurities, containment, and fabrication procedures are retained in files by the Los Alamos National Laboratory Inorganic Elemental Analysis Group.

\section{NUCLEAR MATERIAL CONTENT}

The nuclear material content and total alpha activity for this standard are listed below. Also listed are overall uncertainty estimates at $95 \%$ confidence intervals ( $\mathrm{Cl}$ ) for each component.

\begin{tabular}{|c|c|c|}
\hline Component & Quantity or Value & $95 \% \mathrm{Cl}$ \\
\hline $\mathrm{PuO}_{2}$ in standard & 1.08130 grams & $\pm 0.00163 \mathrm{grams}^{(\mathrm{a})}$ \\
\hline Pu Assay & $87.915 \%$ of $\mathrm{PuO}_{2}$ & $\pm 0.065 \%$ \\
\hline Pu in standard & 0.95062 grams & \pm 0.00144 grams $^{(e)}$ \\
\hline${ }^{241}$ Am Assay & $979.2 \mu \mathrm{g} / \mathrm{g} \mathrm{PuO}_{2}{ }^{*}$ & $\pm 0.2 \mu \mathrm{g} / \mathrm{g}^{(\mathrm{d})}$ \\
\hline${ }^{242} \mathrm{Am}$ in standard & $1.059 \mathrm{mg}^{\circ}$ & $\pm 0.003 \mathrm{mg}^{\{(t)}$ \\
\hline \multicolumn{3}{|l|}{ Isotopic Weight Fraction } \\
\hline${ }^{23 s} \mathrm{Pu}$ & 0.000151 & $\pm 0.000005^{\text {(n) }}$ \\
\hline${ }^{29} \mathrm{Pu}$ & 0.929661 & $\pm 0.000015^{\text {(n) }}$ \\
\hline${ }^{260} \mathrm{Pu}$ & 0.067202 & \pm 0.000007 (n) \\
\hline${ }^{24 t} \mathbf{P u}$ & $0.002327^{\star}$ & $\pm 0.000010^{n}$ \\
\hline${ }^{242} \mathbf{P u}$ & 0.000659 & $\pm 0.000003^{\text {in }}$ \\
\hline Total Alpha Activity in standard & $\begin{array}{c}75.39 \mathrm{mCl} \mathrm{il}^{\star \star} \\
2.789 \mathrm{E}+09 \mathrm{~Bq}\end{array}$ & $\begin{array}{l} \pm 0.22 \mathrm{mCi}^{(2)} \\
\pm 8 \mathrm{E}+06 \mathrm{~Bq}^{(\mathrm{g})}\end{array}$ \\
\hline
\end{tabular}

*Measured value on 10/2/96 " "Effective 10/2/96
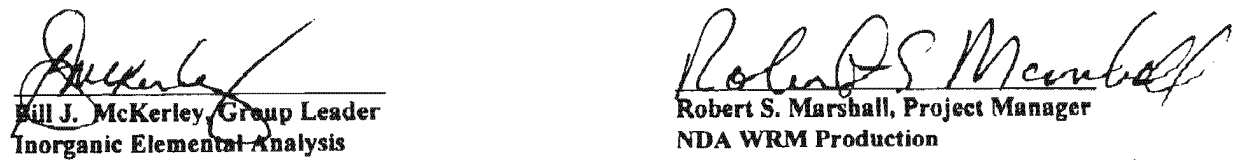


\title{
Znos Alamos \\ Certifitate of Content and Trateability
}

\author{
$\mathrm{PuO}_{2}$-Diatomaceous Earth Standard PDP3.0Pu
}

This NDA standard contains high purity plutonium dioxide dispersed in diatomaceous earth. Quantitative information and uncertainties on the nuclear content of this WRM are listed below. Complete information regarding the $\mathrm{Pu}$ and $\mathrm{Am}$ content, $\mathrm{Pu}$ isotopic ratios, chemical composition, elemental impurities, containment, and fabrication procedures are retained in files by the Los Alamos National Laboratory Inorganic Elemental Analysis Group.

\section{NUCLEAR MATERIAL CONTENT}

The nuclear material content and total alpha activity for this standard are listed below. Also listed are overall uncertainty estimates at $95 \%$ confidence intervals (CI) for each component.

\begin{tabular}{|c|c|c|}
\hline Component & Quantity or Value & $95 \% \mathrm{CI}$ \\
\hline $\mathrm{PuO}_{2}$ in standard & $3.4648 \mathrm{grams}$ & $\pm 0.0029 \mathrm{grams}^{(\mathrm{s})}$ \\
\hline Pu Assay & $87.827 \%$ of $\mathrm{PuO}_{2}$ & $\pm 0.072 \%(b)$ \\
\hline Pu in standard & 3.0430 grams & \pm 0.0026 grams $^{(k)}$ \\
\hline${ }^{201}$ Am Assay & $766.7 \mu \mathrm{g} / \mathrm{g} \mathrm{PuO}_{2}$ & $\pm 2.2 \mu \mathrm{g} / \mathrm{g}^{(d)}$ \\
\hline${ }^{241} \mathrm{Am}$ in standard & $2.656 \mathrm{mg}^{*}$ & $\pm 0.0075 \mathrm{mg}^{(e)}$ \\
\hline \multicolumn{3}{|l|}{ Isotopic Weight Fraction } \\
\hline${ }^{208} \mathrm{Pu}$ & 0.000145 & $\pm 0.000008^{(n)}$ \\
\hline${ }^{239} \mathrm{Pu}$ & 0.937614 & $\pm 0.000013^{(t)}$ \\
\hline${ }^{240} \mathrm{Pu}$ & 0.059445 & $\pm 0.000005^{(n)}$ \\
\hline${ }^{24 i} \mathrm{Pu}$ & $0.002237^{*}$ & $\pm 0.000008^{(n)}$ \\
\hline${ }^{242} \mathrm{Pu}$ & 0.000559 & $\pm 0.000004^{(n)}$ \\
\hline Total Alpha Activity in standard & $\begin{array}{c}234.7 \mathrm{mCi}^{\text {के }} \\
8.682 \mathrm{E}+09 \mathrm{~Bq}\end{array}$ & $\begin{array}{c} \pm 0.8 \mathrm{mCi}^{(\mathrm{s})} \\
\pm 3 \mathrm{E}+07 \mathrm{~Bq}^{(\mathrm{g})}\end{array}$ \\
\hline
\end{tabular}

"Measured value on $7 / 15 / 95$

* Effective $7 / 15 / 95$

overub

(jil I) McKerley, Group Leader

Inorganic Elemental Analysis

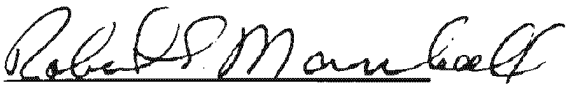

Robert S. Marshall, Project Manager NDA PDP WRM Production 


\title{
Los Alamos National Laboratory Certifitate of Content and $\mathbb{C r a t e a b i l i t y}$
}

\author{
$\mathrm{PuO}_{2}$-Diatomaceous Earth Standard PDP5.0Pu
}

This NDA standard contains high purity plutonium dioxide dispersed ia diatomaceous earth. Quantitative information and uncertainties on the nuclear content of this WRM are listed below. Complete information regarding the $P u$ and Am content, Pu isotopic ratios, chemical composition, elemental impurities, containment, and fabrication procedures are retained in files by the Los Alamos National Laboratory Inorganic Elemental Analysis Group.

\section{NUCLEAR MATERIAL CONTENT}

The nuclear material content and total alpha activity for this standard are listed below. Also listed are overall uncertainty estimates at $95 \%$ confidence intervals $(\mathrm{Cl}$ ) for each component.

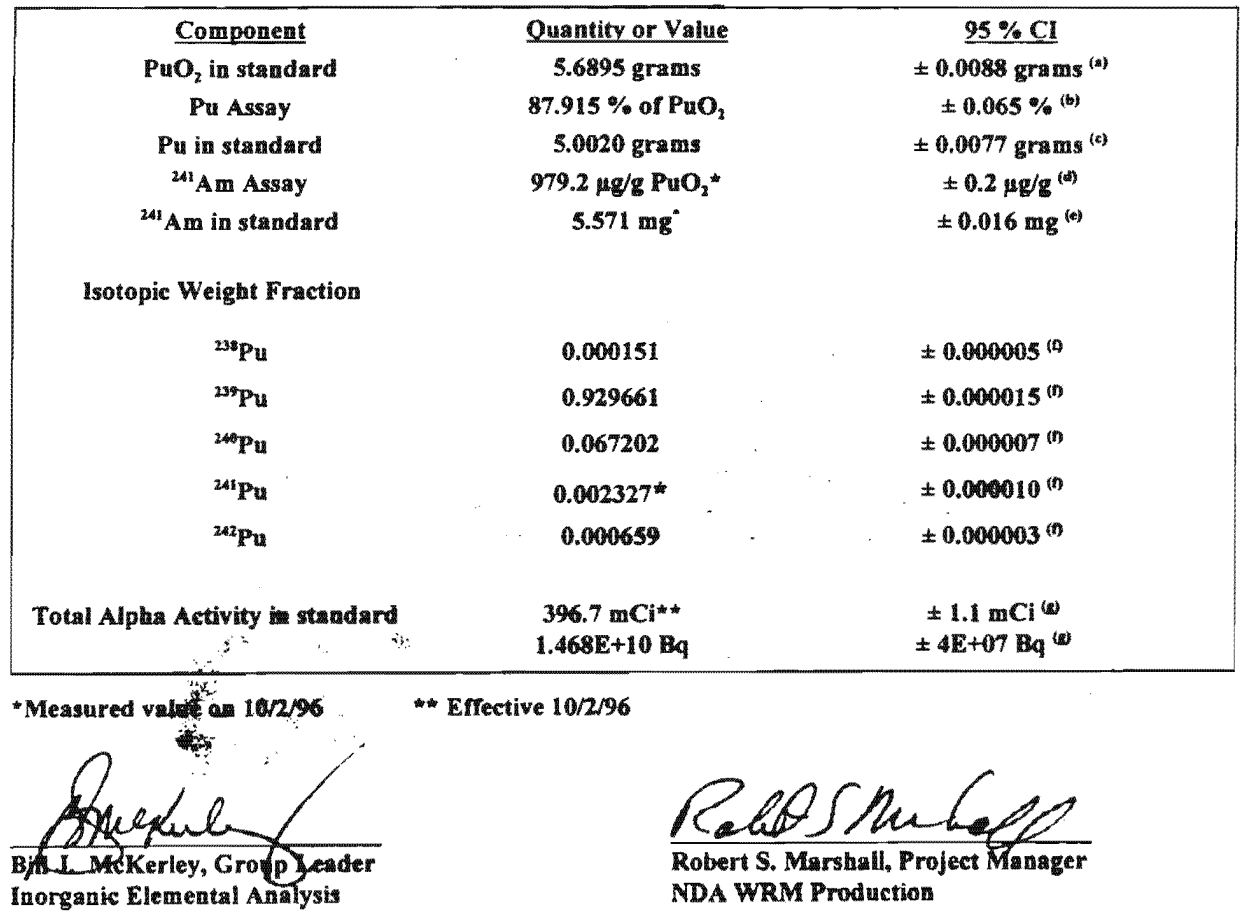




\title{
Ios Alamos Zational inabratory \\ Certifitate of Content and Trateability
}

\author{
$\mathrm{PuO}_{2}$-Diatomaceous Earth Standard PDP10.0Pu
}

This NDA standard contains bigh purity plutonium dioxide dispersed in diatomaceous earth. Quantitative information and uncertainties on the nuclear content of this WRM are listed below. Complete information regarding the $\mathrm{Pu}$ and $\mathrm{Am}$ content, $\mathrm{Pu}$ isotopic ratios, chemical composition, elemental linpurities, containment, and fabrication procedures are retained in files by the Los Alamos National Laboratory Inorganic Elemental Analysis Group.

\section{NUCLEAR MATERIAL CONTENT}

The nuclear material content and total alpha activity for this standard are listed below. Also listed are overall uncertainty estimates at $95 \%$ confidence intervals (CD) for each component.

\begin{tabular}{|c|c|c|}
\hline Component & Quantity or Value & $95 \% \mathrm{CI}$ \\
\hline $\mathrm{PuO}_{2}$ in standard & $11.4570 \mathrm{grams}$ & \pm 0.0096 grams $^{(\mathrm{a})}$ \\
\hline Pu Assay & $87.827 \%$ of $\mathrm{PuO}_{2}$ & $\pm 0.072 \%^{(b)}$ \\
\hline Pu in standard & 10.0624 grams & \pm 0.0085 grams $^{(\mathrm{e})}$ \\
\hline${ }^{241}$ Am Assay & $766.7 \mu \mathrm{g} / \mathrm{g} \mathrm{PuO}_{2}{ }^{*}$ & $\pm 2.2 \mu \mathrm{g} / \mathrm{g}(d)$ \\
\hline${ }^{241} \mathrm{Am}$ in standard & $8.784 \mathrm{mg}$ & $\pm 0.0247 \mathrm{mg}^{(e)}$ \\
\hline \multicolumn{3}{|l|}{ Isotopic Weight Fraction } \\
\hline${ }^{230} \mathrm{Pu}$ & 0.000145 & $\pm 0.000008^{(n)}$ \\
\hline${ }^{239} \mathrm{pu}$ & 0.937614 & $\pm 0.000013^{(n)}$ \\
\hline${ }^{200} \mathrm{Pu}$ & 0.059445 & $\pm 0.000005^{10}$ \\
\hline${ }^{241} \mathrm{Pu}$ & $0.002237^{*}$ & $\pm 0.000008^{(n)}$ \\
\hline${ }^{242} \mathrm{Pu}$ & 0.000559 & $\pm 0.000004^{(n)}$ \\
\hline Total Alpha Activity in standard & $\begin{array}{c}775.9 \mathrm{mCi}^{* *} \\
2.871 \mathrm{E}+10 \mathrm{~Bq}\end{array}$ & $\begin{array}{c} \pm 2.8 \mathrm{mCi}^{(2)} \\
\pm 1 \mathrm{E}+08 \mathrm{~Bq}\end{array}$ \\
\hline
\end{tabular}

"Measured value on 7/15/95

\#* Effective 7/15/95
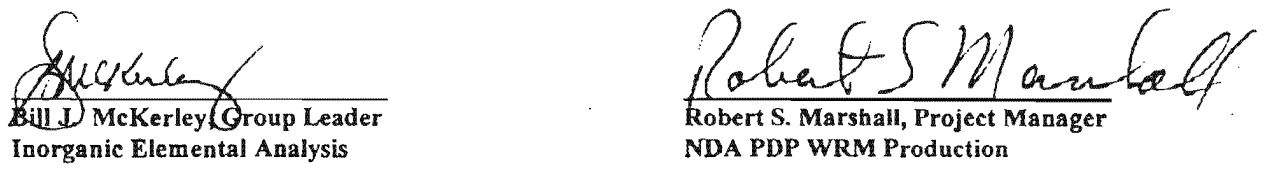


\title{
Los Alamos National Laboratory Cretifitate of Content and Trateability
}

\author{
$\mathrm{PuO}_{2}$-Diatomaceous Earth Standard PDP20.0Pu
}

This NDA standard contains high purity plutonium dioxide dispersed in diatomaceous earth. Quantitative information and uncertainties on the auclear content of this WRM are listed below. Complete information regarding the $\mathrm{Pu}$ and Am content, $\mathrm{Pu}$ isotopic ratios, chemical composition, elemental impurities, containment, and fabrication procedures are retained in Nles by Las Alamos National Laboratory Inorganic Elemental Analysis Group.

\section{NUCLEAR MATERIAL CONTENT}

The auclear material content and total alpha activity for this standard are listed below. Also listed are overall uncertainty estimates at $95 \%$ confidence intervals (CD) for each component.

\begin{tabular}{|c|c|c|}
\hline Component & Quantity or Value & $95 \% \mathrm{CI}$ \\
\hline $\mathrm{PuO}_{2}$ in standard & 22.791 grams & \pm 0.034 grams $^{(s)}$ \\
\hline Pu Assay & $87.915 \%$ of $\mathrm{PuO}_{2}$ & $\pm 0.065 \%$ \\
\hline Pu in standard & 20.037 grams & \pm 0.030 grams $^{(c)}$ \\
\hline${ }^{241}$ Am Assay & $979.2 \mu \mathrm{g} / \mathrm{g} \mathrm{PuO}_{2}$ * & $\pm 0.2 \mu \mathrm{g} / \mathrm{g}(\mathrm{d})$ \\
\hline${ }^{24 x} \mathrm{Am}$ in standard & $22.32 \mathrm{mg}^{*}$ & $\pm 0.07 \mathrm{mg}(\mathrm{es}$ \\
\hline \multicolumn{3}{|l|}{ Isotopic Weight Fraction } \\
\hline${ }^{228} \mathrm{Pu}$ & 0.000151 & \pm 0.000005 ? \\
\hline${ }^{239} \mathrm{Pu}$ & 0.929661 & $\pm 0.000015^{(n)}$ \\
\hline${ }^{260} \mathrm{Pu}$ & 0.067202 & $\pm 0.000007^{(n)}$ \\
\hline${ }^{261} \mathrm{Pu}$ & $0.002327^{*}$ & $\pm 0.000010^{n}$ \\
\hline${ }^{202} \mathrm{Pu}$ & 0.000659 & $\pm 0.000003^{m}$ \\
\hline Total Alpha Activity in standard & $\begin{array}{c}1589 \mathrm{mCi} \text { औ* } \\
5.880 \mathrm{E}+10 \mathrm{~Bq}\end{array}$ & $\begin{array}{c} \pm 5 \mathrm{mCi}^{(w)} \\
\pm 2 \mathrm{E}+08 \mathrm{~Bq}\end{array}$ \\
\hline
\end{tabular}

* Measured value on 10/2/96

Effective $10 / 2 / 96$
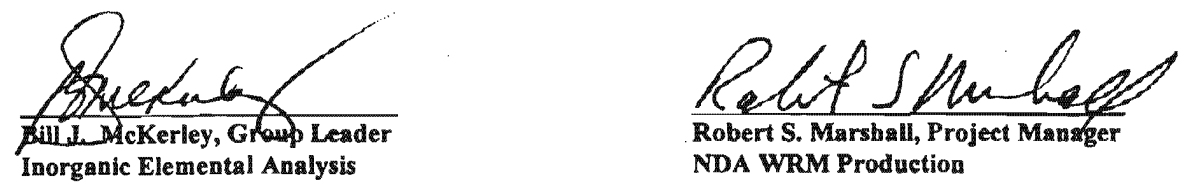
Los Alamos

NATIONAL LABORATORY

\section{Memorandum}

Nuclear Material Technology

NMT-1 Analytical Chemistry

Standard Fabrication Team, MS G740

Los Alamos, New Mexico 87545
To/MS: Diane Otero-Bell, NMT-4 LANL

From/MS: Sandra L. Mecklenburg, NMT-1/G740

Phone/FAX: (505) 665-7182/(505) 665-4737

Date: May 2, 2000

Reference: NMT-1-00-026

Below is information on the large particle plutonium sources which are being shipped to NMT-4. You are receiving seven items with different masses of $\mathrm{Pu}$ per item and different particle sizes. The label notation gives the approximate grams of $\mathrm{Pu}$ (i.e. $\mathrm{PDP} 5.0 \mathrm{Pu}$ is $\sim 5.0 \mathrm{~g}$ of $\mathrm{Pu}$ ) and the particle size in millimeters (i.e. $2.0 \mathrm{~mm}$ indicates the particle sizes are $\sim 2.0 \mathrm{~mm}$ ). The information listed below is being provided as a summary. Formal certificates containing error analysis will be sent separately when they are ready.

Summary information on the large particle Pu sources:

\begin{tabular}{|lccc|}
\hline WRM ID Number & Mass of Pu (g) & Mass of ${ }^{239} \mathrm{Pu}(\mathrm{g})$ & Dose Rate (contact) \\
\cline { 4 - 5 } PDP5.0Pu 2.5mm & 5.05020 & 4.69604 & $1.3 \mathrm{mR} / \mathrm{h}$ \\
PDP5.0Pu2.0mm & 5.07593 & 4.71996 & $1.5 \mathrm{mR} / \mathrm{h}$ \\
PDP5.0Pu1.0mm & 4.98867 & 4.63882 & $2.0 \mathrm{mR} / \mathrm{h}$ \\
PDP5.0Pu0.5mm & 5.01811 & 4.66620 & $2.4 \mathrm{mR} / \mathrm{h}$ \\
PDP0.5Pu2.0mm & 0.50127 & 0.46611 & $0.3 \mathrm{mR} / \mathrm{h}$ \\
PDP15.0Pu2.0mm & 15.67266 & 14.57355 & $4 \mathrm{mR} / \mathrm{h}$ \\
PDP30.0Pu2.0mm & 30.30469 & 28.17945 & $6 \mathrm{mR} / \mathrm{h}$ \\
& & & \\
${ }^{\text {Pu Isotope* }}$ & Weight \% & & \\
${ }^{238} \mathrm{Pu}$ & 0.01490 & & \\
${ }^{239} \mathrm{Pu}$ & 92.98709 & & \\
${ }^{240} \mathrm{Pu}$ & 6.72067 & & \\
${ }^{241} \mathrm{Pu}$ & 0.21142 & & \\
${ }^{242} \mathrm{Pu}$ & 0.06592 & & \\
${ }^{241} \mathrm{Am}$ & $1162.8 \mathrm{ppm}$ & \\
$\mathrm{Pu}$ assay & $0.87778 \mathrm{~g} \mathrm{Pu} / \mathrm{g} \mathrm{PuO}{ }^{* *}$ & \\
\hline
\end{tabular}

*Decay corrected to $9 / 28 / 98$ **Analysis date $9 / 28 / 98$ 


\title{
Los Alamos National Laboratory Certifitate of Content and Trareabilite
}

\author{
$\mathrm{PuO}_{2}$-Diatomaceous Earth Standard Rant 50-1
}

This NDA standard contains high purity plutoalum dioxide dispersed in diatomaceous earth. Quantitative information and uncertainties on the nuclear content of this WRM are listed below. Complete information regarding the Pa and Am content, $\mathrm{Pu}$ wotopic ratios, chemical composition, elemental impurities, containaneat, and fibrication procedures are retained in flles by the Los Alamos National Laboratory CMR Analytical Chemistry Gronp.

\section{NUCLEAR MATERIAL CONTENT}

The nuclear material comtent and total alpha activity for this standard are listed below. Also listed are overall uncertainty estimutes $85 \%$ confidence intervals (CI) for each component.

\begin{tabular}{|c|c|c|c|}
\hline Component & Quantity or Value & $95 \% \mathrm{Cl}$ & \\
\hline $\mathrm{PuO}_{2}$ in stadiard & 56.9204 grams & $\neq 0.05292$ grams $^{(n)}$ & \\
\hline Pu Assay . & $87.897 \%$ of $\mathrm{PuO}_{2}$ & $\pm 0.081 \%(b)$ & \\
\hline Pu in standard & 50.03132 grams & \pm 0.04652 grams $^{(e)}$ & \\
\hline${ }^{241}$ Am Assay & $1140.3 \mathrm{Mg} / \mathrm{g} \mathrm{POO}_{2}$ & $\pm 0.3 \mu \mathrm{g} / \mathrm{g}^{(d)}$ & \\
\hline${ }^{2 A 1} \mathrm{~A}$ m in standard & $64.89 \mathrm{mg}^{*}$ & $\pm 0.43 \mathrm{mag}^{(e)}$ & \\
\hline Isotopic Weight Fraction & & & $\therefore$ \\
\hline${ }^{238} \mathbf{P u}$ & 0.000149 & $\pm 0.000005^{6}$ & \\
\hline${ }^{239} \mathrm{Pu}$ & 0.929845 & $\pm 0.000015^{18}$ & \\
\hline${ }^{240} \mathbb{P u}$ & 0.067206 & $\pm 0.000007^{(1)}$ & \\
\hline${ }^{241} \mathrm{Pu}$ & $0.002141^{*}$ & \pm 0.000009 & \\
\hline${ }^{242} \mathrm{Pu}$ & 0.000659 & $\pm 0.000003^{(n)}$ & \\
\hline Total Alpha Activity in standard & $\begin{array}{c}3997 \mathrm{mCi} \\
1.479 \mathrm{E}+11 \mathrm{~Bq}\end{array}$ & $\begin{array}{c} \pm 11 \mathrm{mCi}^{(\mathrm{m})} \\
\pm 4 \mathrm{E}+08 \mathrm{~Bq}^{(}\end{array}$ & \\
\hline
\end{tabular}

*Decay corrected value on 6/25/98 * Efrective 6/25/98

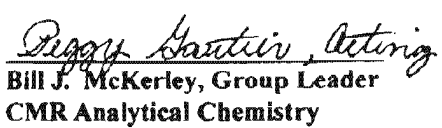

Bill J. Mckerley, Group Leader CMR Analytical Chemistry

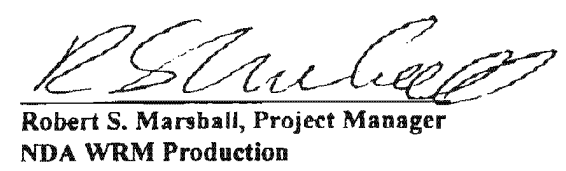

NDA WRM Production

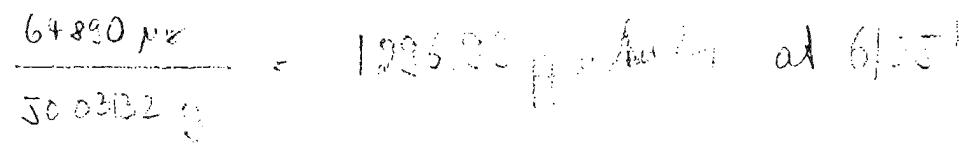




\title{
Los Alamos National Laboratory Certifitate of Content and Trateability
}

\author{
$\mathrm{PuO}_{2}$-Diatomaceous Earth Standard Rant $50-2$
}

This NDA stamdard contains high purity plutonium dioxide dispersed in diatornaceous earth. Quantitative information and uncertainties on the nuclear content of this WRM are listed below. Complete information regarding the Prand Am content, Pu isotople ratios, chemical composition, elemental partices,

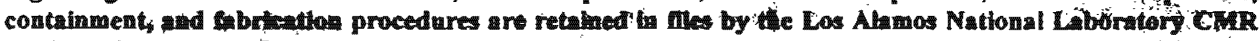
Antlytical Chemistry Groap.

\section{NUCLEAR MATERIAL CONTENT}

The nuclear material content and total aipha activity for this standard are listed below. Also listed are overall uncertainty estimates at $95 \%$ confidence intervals (CD) for each component.

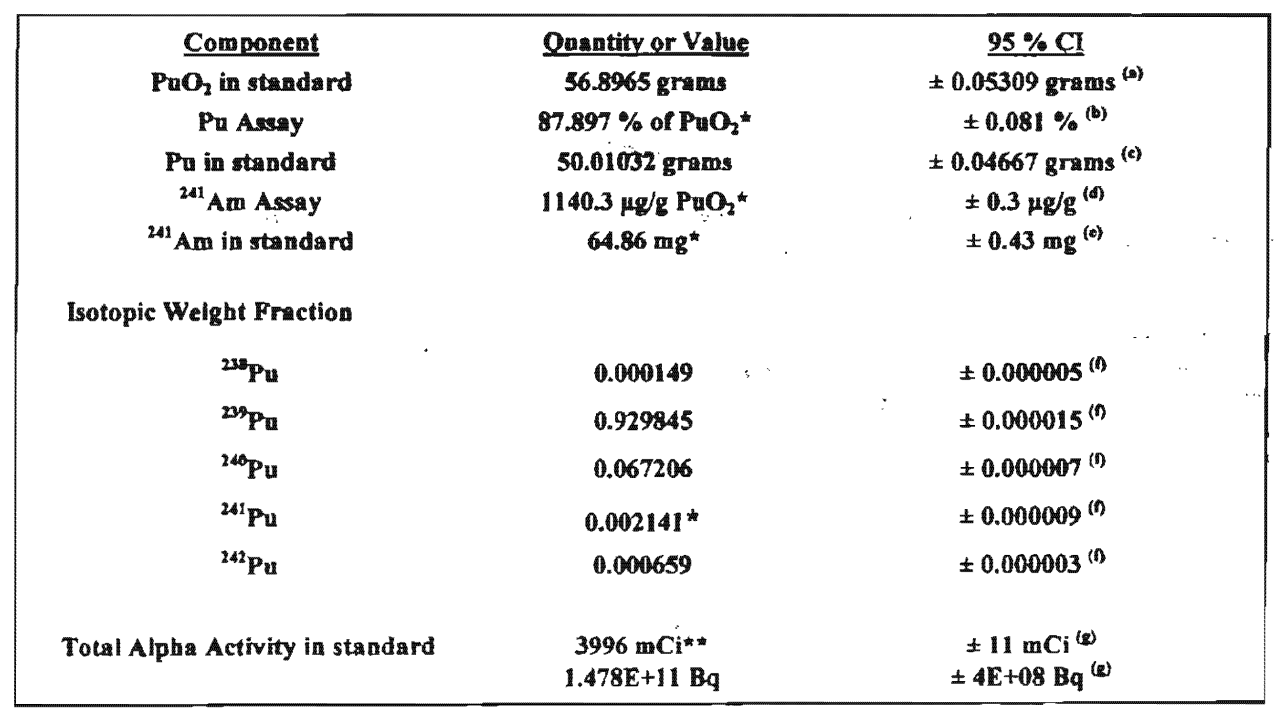

\#Decay corrected value on 6/25/98 * Effective 6/25/98

Beges, Sautie, Acting

CMR Analytical Chemistry

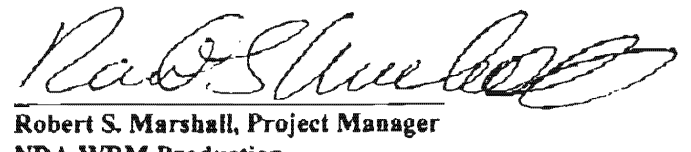

NDA WRM Production

$$
\operatorname{pim} A_{\text {w }} \mathrm{iul}=\frac{(64.86 \times 1000) \mathrm{Nq}}{50.01032 \mathrm{~g} P_{v}}=1296.93 \pm 8.7
$$




\title{
Los Alamos National Laboratory Certifitate of Content and Crateability
}

\author{
$\therefore \quad i^{p *}+2$ \\ $\mathrm{PuO}_{2}$-Diatomaceous Earth Standard Rant 50-3
}

This NDA standard contains high parity plutonium dioxidestepersed in diatomaceous earth. Quantitative information and uncertainties on the nuclear content of this WRM are listed below. Complete information regarding the Pu and Am content, Pu tsotoplc ratios, chemical composition, elemental impurities, containment, and fabrication procedures are retalnte in nits by the Los Alamos National Laboritory CMR Analytical Chemlatry Group.

\section{NUCLEAR MATERLAL CONTENT}

The nuclear material content and total alpha activity for this standard are listed below. Also listed are overall uncertainty estimates at $95 \%$ confidence interyals (CI) for ech component.

\begin{tabular}{|c|c|c|c|c|}
\hline Component & Quantity or Value & & $95 \% \mathrm{CI}$ & \\
\hline $\mathrm{PuO}_{2}$ in standard & 56.9262 grams & & \pm 0.05298 grams $^{(a)}$ & \\
\hline Pu Assay & $87.897 \%$ of $\mathrm{PuO}_{2}$ & & $\pm 0.081 \%(b)$ & \\
\hline Pu in standard & $50.03642 \mathrm{grams}$ & & $\pm 0.04657 \mathrm{grams}^{(\mathrm{c})}$ & \\
\hline${ }^{241}$ Am Assay & $1140.3 \mu \mathrm{g} / \mathrm{g} \mathrm{PuO} \mathrm{Pu}_{2}^{*}$ & $\therefore$ & $\pm 0.3 \mu \mathrm{g} / \mathrm{g}(\mathrm{d})$ & \\
\hline${ }^{241} \mathrm{Am}$ in standard & $64.90 \mathrm{mg}$ & & $\pm 0.43 \mathrm{mg}{ }^{(e)}$ & \\
\hline Isotopic Weight Fraction & & & $\therefore$ & , ' \\
\hline${ }^{219} \mathrm{Pu}$ & 0,000149 & & $\pm 0.000005^{(n)}$ & \\
\hline${ }^{209} \mathrm{Pu}$ & 0.929845 & & $\pm 0.000015^{(n)}$ & \\
\hline${ }^{200} \mathrm{Pu}$ & 0.067206 & & $\pm 0.000007^{10}$ & \\
\hline${ }^{211} \mathrm{Pu}$ & $0.002141^{\star}$ & & $\pm 0.000009^{17}$ & \\
\hline${ }^{202} \mathrm{Pu}$ & 0.000659 & & $\pm 0.000003^{(n)}$ & \\
\hline Total Alpha Activity in standard & $\begin{array}{c}3998 \mathrm{mCl} \mathrm{m}^{* \star} \\
1.479 \mathrm{E}+11 \mathrm{~Bq}\end{array}$ & & $\begin{array}{c} \pm 11 \mathrm{mCl}^{(8)} \\
\pm 4 \mathrm{E}+08 \mathrm{~Bq}\end{array}$ & \\
\hline
\end{tabular}

-Decay corrected value on $6 / 25 / 98$ EIfective $6 / 25 / 98$

Pegzh Santriv, Aeterig CMR Analytical Chemistry

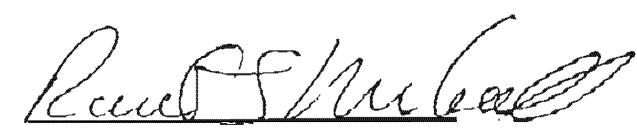

Robert S. Marshall, Project Manager NDA WRM Production 